\title{
Rebuilding the Lives of Former Drug Dependents in Davao City through the Sagop Kinabuhi Program 2
}

\author{
Mervin G. Gascon ${ }^{1}$ and Gladys Florangel I. Ortiz ${ }^{2}$
}

\begin{abstract}
Drug dependency is strongly connected with poverty and gender issues. An initiative of the University of Southeastern Philippines' Extension Office and the Archdiocesan Action Center of Davao City, the Sagop Kinabuhi Program 2 $\left(\mathrm{SKP}_{2}\right)$ aims to provide socioeconomic opportunities to former drug users. This paper details the participatory action research that involves this marginalized sector, their families and the representatives of the various government and nongovernment agencies comprising the $\mathrm{SKP}_{2}$ platform. Using critical systemic approach to address issues related to drug dependency, poverty and vulnerability, the participants were led to regain their self-respect and self-confidence through various pathways designed to enhance their skills and capabilities. Their narratives and the findings suggest that
\end{abstract}

1 Mervin G. Gascon is a faculty of the College of Development Management of the University of Southeastern Philippines. He is currently the Director of the Extension Division of the same institution. The lead author acknowledges the funding and administrative support of the USEP to SKP2 through its University President Dr. Lourdes C. Generalao and the able guidance and supervision of the Vice President for Research, Development and Extension Dr. Danilo B. Pacoy. Sincerest acknowledgment is given to the project leaders of SKP2: Dr. Rosfe Corlae D. Badoy, Assoc. Prof. Gladys Florangel I. Ortiz and Dr. Orvil G. Basug for their valuable contributions.

2 Gladys Florangel I. Ortiz is a faculty of the College of Business Administration. She is currently the Program Head of the MS in Development Administration and MS in Environmental Resource Management programs. She is also the Director of the Mindanao Center for Policy Studies. 
the dominant strategies being used to address the problems confronted by the drug dependents and their families are positivist and systematic. They do not reflect the individual voice, choice and agency of the victims of drug dependency. Community drug rehabilitation therefore must be systemic and inclusive to ensure that the strategies used are reflective of the real interests of this sector and their families.

Keywords: Community drug rehabilitation, voluntary submission, capabilities approach

The University of Southeastern Philippines (USeP) has conceptualized and implemented the Sagop Kinabuhi Program 2 (SKP2) to help address the socio-economic needs of those who turned themselves in to Oplan Tokhang. Oplan Tokhang, the anti-drug campaign started by former Davao City Police Office's (DCPO) director Ronald dela Rosa, is derived from the Cebuano word "Toktok-Hangyo" meaning "knock and plead". Under the scheme, police personnel make a polite request to suspected drug personalities to surrender or stop using drugs.

The Program champions the interests of those who, after tokhang, have been branded and recorded as offenders, deviants and drug addicts in positivist profiling approaches which only target the main question: how many drug addicts are in the community? The SKP2 approach tries to be less about profiling but more on individual case management. The Program adheres to the principles of the capabilities approach (Nussbaum, 2011; Sen, 1999) arguing that what they have been confronted right now after tokhang is not just the issue of drug dependency. It explores the complex deprivation experiences of former drug dependents being poor, isolated, stigmatized, physically weak, and vulnerable. Its belief is that if we are only able to focus on certain limited aspects and are not able to consider the critical importance of their feelings, anxiety, 
happiness and dreams, then we might not become successful because what we are basically dealing with are humans too.

Many similar initiatives around the country especially those spearheaded by the local government units (LGUs) call their clients "reformists" (Dizon, 2016), "surrenderers" (Philippine Star, 2017) and "former drug addicts" (Sallaverria, 2016). In SKP2, they are called voluntary submission for reformation persons (VSRPs). Quite a mouthful but the main intention is to establish a conceptual and practical aversion from the stigma of banal branding of VSRPs being called addicts. In the Program, they are called by their names as the Program always strives to make close and supportive relationships with them, their families and community leaders. Everyone engaged in the SKP2 platform is regarded as friends and partners.

As partners, all those involved are encouraged to be close to each other, maintaining a healthy and productive social distance. It is important to make the social relationship open, congenial and supportive to establish genuine trust among each other. The SKP2 platform allows leaders/experts and VSRPs and their families to work together. The Program ensures that each has an active and strategic role to play. The platform enhances their listening capabilities such that they are able to consider their experiences as important as others'. This means to say that the ideas of its leaders and experts do not build the whole decisionmaking discourse, but includes the voice, choice and agency of everyone especially the VSRPs and their families.

The objectives of this paper are first, to present the implementation experiences of all the partners working in the SKP2; and second, to highlight the Program's significant accomplishments. In showcasing the experiences, the paper shall describe the methods and tools used to carry out the Program's harmonized efforts towards providing basic life, livelihood and leadership skills for the VSRPs and their families. 


\section{Approach and methodology: The Program's process of renewal for VSRPs}

This paper centers on this idea upon which SKP2 is anchored: the enhancement of life and livelihood skills among the VSRPs and their families for sustainable social, economic and psychological enhancement and renewal.

The process of renewal requires the whole community to actively work together to ensure success. Church leaders, social workers, researchers, community leaders and other experts are needed to explore and address systemically the issues confronted by the VSRPs. As a platform, SKP2 offers the VSRPs need-based pathways, illustrated in Figure 1.

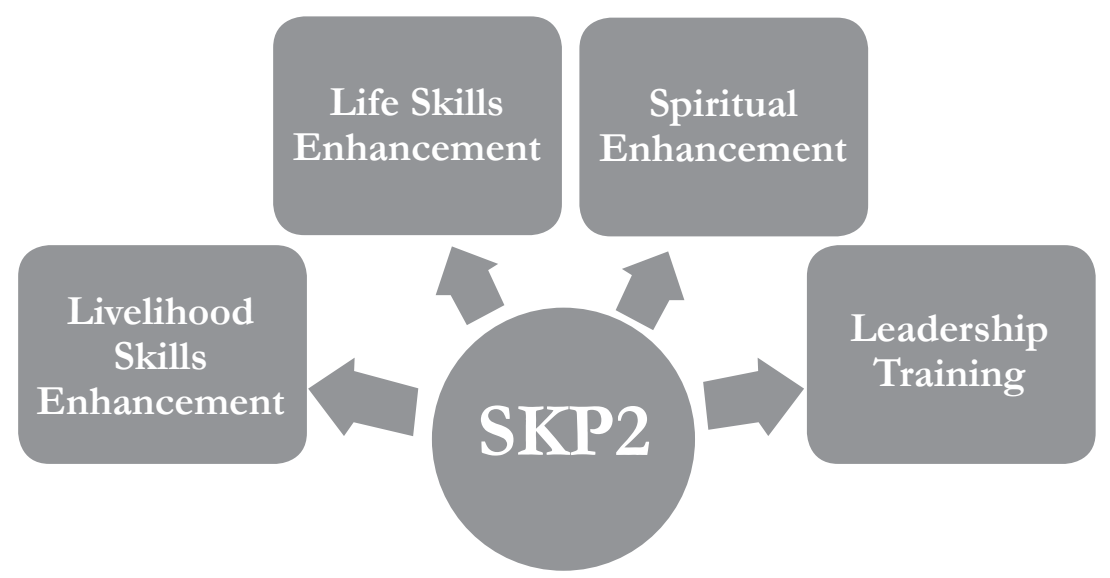

Figure 1. VSRPs’ Need-Based Pathways

The Program started off with a series of social gatherings, followed by psychosocial and spiritual training (PST) for 19 weeks facilitated by the Archdiocesan Social Action Center under the Archdiocese of Davao. After the PST, a series of consultations with the VSRPs and their families was conducted to obtain their preferred skills training. Their expressed 
preferred trainings were the following: a) Shielded Metal Arch Welding (SMAW) NC 1; b) Driving NC2; and, c) Small Engine Repair NC2. These trainings were held at the USeP Obrero Campus for 15 weeks.

After each major training completion, a moving up ceremony with the VSRPs, their families, community leaders and SKP2 agency partners would be held to celebrate and give recognition to the outstanding accomplishments of top performing trainees. On the same day, a medical mission and team building activities were held.

Individual case files of the VSRPs are kept and managed to track their progress and record in a timely manner their physical, mental, social and economic needs. Using the progressive case files maintained by seasoned USeP faculty members in the discipline of psychology and social work, the case files help the Program customize its approach in handling individual needs during trainings and other social engagements.

\section{Results and Discussion}

\section{A systemic approach in enhancing VSRPs' participation}

The SKP2 uses a systemic approach in exploring the issues and concerns confronted by partners engaged in the platform. The Program works with the VSRPs, their families, community leaders and the agency representatives. It always tries to challenge the current ways of thinking by engaging with as many stakeholders at the individual, family, community (barangay to city) and the inter-agency levels in the SKP2 platform. Problems confronted by the partners mainly from the VSRPs and their families are usually being listened to if they wish to be supported. Through its Facebook page ${ }^{3}$, the staffs mobile numbers and the office landline are shared with them and they call or text the staff

3 www.facebook.com/SagopKinabuhiProgram2 
like they are real family members asking for help and advice. According to one of the program participants:

Nalipay ko nga naay $\mathrm{SKP}_{2}$ sa USeP kay mas makadasig sa ako para magbag-o ug magpartisipar sa mga kalihukan sa palibut. Lisud kung walay mga tinood na amigo ug suporta para sa kabag-uhan na akong ginapangarap karung panahona.

(I am happy that there is SKP2 in USeP because I am motivated to really change and be an active participant in the community activities. It would be difficult if I don't have true friends and real support in the change that I now truly aspire for.)

Mary, VSRP

Evidently, SKP2 is interested in improving the well-being and life chances of the VSRPs, their families and communities. The VSRPs and their families deserve decent and just social minimum support or provision (Nussbaum, 2011) to enhance their basic skills and capabilities. Going beyond improving their technical or livelihood skills, it targets to enhance their participation skills to become more socially adept and morally/spiritually inclined individuals. This is done by engaging with them directly in practically all stages of the Program.

\section{Building strong partnerships}

The SKP2 platform has been able to attract more support in cash and in kind from the community. Table 1 presents the outstanding partners and their contributions to our platform. The SKP2 is chosen amongst all universities and colleges in Region XI to represent the 
academe in the Regional Anti-Drug Abuse Council (RADAC). The role of the Program is provision of RADAC research-based reports and other information and education materials for the use of local governments and other partners in the implementation of rehabilitation programs in their respective areas.

Table 1. SKP2 partners and their outstanding contributions

\begin{tabular}{|c|c|}
\hline Partners & Significant Contributions \\
\hline $\begin{array}{l}\text { Department of } \\
\text { Social Welfare and } \\
\text { Development, } \\
\text { RO XI }\end{array}$ & $\begin{array}{l}\text { Apart from their active participation in partners' } \\
\text { meetings, mid-year and year-end evaluations, moving- } \\
\text { up ceremonies and case management workshops, } \\
\text { DSWD ROXI awarded to SKP2 the Skills Training } \\
\text { Grant of P2,956,4l1.60. }\end{array}$ \\
\hline $\begin{array}{l}\text { Knights of } \\
\text { Columbus, } 0988 \\
\text { Assembly - } \\
4^{\text {th }} \text { Degree }\end{array}$ & $\begin{array}{l}\text { K of C extended to the VSRPs and their families food } \\
\text { packs good for one month to help ensure that the } \\
\text { basic needs of the VSRPs and their families while on } \\
\text { training are partially supported. }\end{array}$ \\
\hline $\begin{array}{l}\text { Talomo Police } \\
\text { Station, Davao City }\end{array}$ & $\begin{array}{l}\text { The station is responsible for the conduct of random } \\
\text { drug tests for the VSRPs in their barangays. Focal } \\
\text { persons of the partner barangays assist the policemen } \\
\text { from Talomo Station to ensure that smooth, organized } \\
\text { and ethical processes are observed as agreed in the } \\
\text { SKP2 platform. }\end{array}$ \\
\hline $\begin{array}{l}\text { Department of } \\
\text { Education Davao } \\
\text { City Division } \\
\text { Schools }\end{array}$ & $\begin{array}{l}\text { The office is leading and conducting the community- } \\
\text { based offering of primary and secondary education } \\
\text { programs among some VSRPs and family members. }\end{array}$ \\
\hline
\end{tabular}




\begin{tabular}{|l|l|}
\hline Partners & Significant Contributions \\
\hline Department of Labor & $\begin{array}{l}\text { DOLE commits to take charge of the full expense } \\
\text { of conducting midyear and year-end evaluation } \\
\text { activities. The mid-year evaluation was conducted } \\
\text { on July 25-26, 2017. SKP2 partners, barangay focal } \\
\text { and Employment, } \\
\text { RO XI } \\
\text { the program management team participated in the } \\
\text { activity. DOLE has also approved the cash-for-work as } \\
\text { a social amelioration scheme for VSRPs and families } \\
\text { after their skills training and while they are still } \\
\text { looking for a stable job or livelihood. The scheme is } \\
\text { part of the after-care program to ensure the successful } \\
\text { reintegration of our VSRPs in their communities. }\end{array}$ \\
\hline Archdiocesan Social \\
Action Center & $\begin{array}{l}\text { ASAC spearheads the psychosocial-spiritual } \\
\text { enhancement activities for the VSRPs. ASAC } \\
\text { representatives have been contracted to produce } \\
\text { modules and deliver seminars and workshops for } \\
\text { VSRPs and their families mainly on topics related to } \\
\text { spirituality and moral recovery. }\end{array}$ \\
\hline
\end{tabular}

SKP2 is able to attract funds for the implementation of various skills and leadership trainings of the VSRPs and their families. Efforts are made to convince other groups to join SKP2 especially those that can help provide social amelioration in the form of food packs to the VSRPs so that while they are actively completing their training requirements, they can still ably provide the basic needs of their families. From the outset, the Program was confronted by the issue of VSRPs dropping out from the Program in favor of work. However, with the support of the Department of Social Work and Development (DWSD), Department of Labor and Employment (DOLE), Knights of Columbus and others, a decent supply of food packs and cash-for-work assistance for the VSRPs and their families is being provided while they are on training. 


\section{Significant accomplishments: Thorough documentation and sharing of best practices}

What makes SKP2 unique amongst all community drug rehabilitation programs is that it collects quantitative and qualitative data from various stages and collection points while engaged with its partners. In all its meetings for planning, evaluation, special interviews and even mundane conversations, tape recorders, videos, pictures, minutes, transcripts and field notes are used. This helps the Program 'make sense' (Creswell, 2007) of our emic views which are used to support our arguments using etic (theoretical) perspectives - from which 'negotiated knowledge' (Gascon \& McIntyre-Mills, 2018) is produced in the form of action research reports.

In doing these research activities, strict confidentiality is observed. All documents, audio and video files that contain the identities of the VSRPs are kept in a secured file system at the Extension Division Office in USeP. All reports for public dissemination do not contain any lead information towards identifying any of the VSRPs. Field notes collected from conversations are coded while aliases are used in the case study quotes in the research reports. The social workers, psychologists and other experts representing the agency partners of SKP2 in the action researches done in the program are actively involved. They are especially involved in the data gathering; the Program staff process the data and draft the initial reports. The initial reports are shown to them for their comments. Focus group discussions with the VSRPs are held to validate the report or plan and their help is sought to help the staff finalize the report after their final reading. 
Appreciation by the stakeholders of this part of the process (documentation) is revealed by one of our partners:

As a social worker engaged with the other partners in SKP2 in USeP, I have become prouder of my enhanced personal, leadership, and research skills. I offer my services by giving technical and administrative inputs for SKP2 to increase its funding from my organization and my network. I thought my work, and the value of it is just going to be about what I am used to do. Little did I know that I am also capable of researching, planning and doing with our VSRPs. What I like the most is the recognition I get from my organization and other people for the quality and relevance of the reports, information and education campaigns (IECs), and other public presentations that bear our agency's logo. In my organization, we are good at implementation but we have a problem with documentation. SKP2 has helped me address this problem.

Dahlia, SKP agency partner representative

Moreover, the action researches produced by the team are disseminated to various publics. They are meant to inform the publics of the SKP2 and enter into critical debate with wider stakeholders; and by receiving scholarly critiques, the quality of the papers presented is improved with chances of further dissemination or publication in reputable publishing houses here and abroad.

Papers that discussed the SKP2 framework and accomplishments have been read in conferences, such as: "Life After Tokhang: Voluntary Submission for Reformation Persons (VSRP) in Davao City" (M.G. Gascon, winner of Best Paper in the 3rd National Multi-Sectoral Extension Services Convention of the University of Northern Philippines, 
2017); "Capabilities Approach in Community Drug Rehabilitation in Davao City" (R. Badoy, et.al., presented in the Philippine Political Science Association International Conference: Multilevel Governance, Davao City, 2018); and "Exploring the Life Chances of the Voluntary Submission for Reformation Persons (VSRPs) of the Sagop Kinabuhi Program 2 in Davao City" (L.D. Galicha and M.G. Gascon, presented in the 1st International Conference on Inmates Transformative Education for Successful Re-entry, Davao City). The Program has likewise come up with a paper whose central subject involved the "Silenced Stories of Women Drug Dependents in Davao City" (J. Dulong and M.G. Gascon).

It is noteworthy that SKP2, to date, is able to reshape the theoretical landscapes by identifying the gaps and adding more and fresher insights towards the promotion of human rights, well-being and criminal justice; and influenced the community drug rehabilitation discourse and policies.

\section{Inclusion, engagement, and our negotiated reality}

The SKP2 serves multiple roles in reshaping the way drug dependency is approached under the community drug rehabilitation platform of the country. Its engagement is not only limited to a number of people and places but also includes the social, political, economic and academic communities and tap their functional and strategic ideas and actions to enrich the experiences of VSRPs as professionals and improve their wellbeing and life chances as well as those of their families.

The platform of the SKP2 is to ensure that genuine learning happens, where both the experts in various fields and the VSRPs and their families learn how to plan, implement and evaluate the success of SKP2's undertakings. 
The success being reaped does not only pertain to how the Program is able to facilitate the enhancement of life, livelihood and leadership skills of the VSRPs and their families. Agency partners and us being faculty members and staff of the University who are directly and indirectly engaged in the Program are able to enrich our personal and professional experiences as well. We realize that rebuilding the lives of the VSRPs and their families after tokhang requires experts or knowledge sharers to be genuine and collegial in order for intentions to fit well with personal, professional and program goals. On the other hand, our partners have heavy responsibilities to carry, yet they persevere. In a sense, our Program has produced a dynamic disposition amongst us: "They have become us in the ways we think and embolden ourselves to strategically participate, and we have become them in the ways we must understand the context of their complex deprivation. Our negotiated reality has put us united and strong in the Program."

\section{Lessons and plans for the future}

Community drug rehabilitation should be approached using multifaceted strategies that former drug dependents themselves and their families could suggest or offer.

In the pipeline, to be able to help improve life skills of the VSRPs, the Program intends to conduct more training activities, such as on the following: performing arts and visual arts, urban gardening, gender mainstreaming, cookery, advanced leadership, financial literacy, solid waste recycling as well as the preparation and conduct of a training module (TM) for VSRPs who are qualified to become trainers.

Clearly, former drug dependents deserve a life too. They deserve to be given opportunities such that they are pumped into productive economy. They could be re-educated, convinced to change and remain 
steadfast in their goals towards renewal and reintegration to their families and communities. They need to feel that life after tokhang is better and that they no longer are immigrants in their very own families and communities.

Another essential lesson to be derived from the Program relates to the merits gained from participatory action research: that it requires experts and leaders to engage strategically and genuinely with the former drug dependents and their families. The process requires that the Program does not capitalize on data gathering, but instead treat data as a means for everyone to critically reflect and eventually improve things the next time around. Therefore, a platform where both extension service and research are conducted requires that they engage with the partners directly in the process of learning together whereby increasing the chances of attaining success and relevance in the lives of marginalized sectors of society. 


\section{References}

Chambers, R. (1995). Poverty and livelihoods: whose reality counts? Environment and Urbanization, 7(1), 173-204.

Creswell, J. W. (2007). Qualitative Inquiry and Research Design: Choosing Among Five Approaches (Second ed.). US: Sage Publications, Inc. .

Dizon, N. (2016). Reformed drug users to become bet takers? Inquirer.net. Retrieved from http://newsinfo.inquirer.net/824765/reformeddrug-users-to-become-bet-takers

Gascon, M. (2017). Empowering Indigenous People to Actualise their Voice, Choice and Agency in Rural Development Planning in Mindanao. In J. McIntyre-Mills and Y. Cocoran Nantes (Eds.), Contemporary Systems Thinking: Balancing Individualism and Collectivism to Support Social and Environmental Justice (Vol. 1). New York: Springer

Gascon, M., and McIntyre-Mills, J. (2018). Empowering Indigenous People: Voice, Choice and Agency in Rural Development Planning in Mindanao. In J. McIntyre-Mills, N. Romm, and Y. Corcoran-Nantes (Eds.), Balancing Individualism and Collectivism: Social and Environmental Justice (pp. 319-386). Cham: Springer International Publishing.

Nussbaum, M. (2011). Creating Capabilities: The Human Development Approach. London: The Belknap Press of Harvard University Press.

Philippine Star. (2017). Drug war surrenderers breach 1M mark. Philippine Star. Retrieved from http://www.philstar.com/ headlines/2017/01/01/1658665/drug-war-surrenderers-breach$1 \mathrm{~m}$-mark

Sallaverria, L. (2016). More than 1 million drug users, pushers have surrendered, says Palace. Pbilippine Daily Inquirer.

Sen, A. (1999). Development as Freedom. New York: Alfred A. Knopf. 